CLINICAL STUDY

\title{
Somatostatinergic ligands in dopamine-sensitive and -resistant prolactinomas
}

\author{
Alessandra Fusco ${ }^{1}$, Ginette Gunz ${ }^{1}$, Philippe Jaquet ${ }^{1}$, Henry Dufour ${ }^{2}$, Anne Laure Germanetti ${ }^{3}$, Michael D Culler ${ }^{4}$, \\ Anne Barlier ${ }^{1,3}$ and Alexandru Saveanu ${ }^{1,3}$ \\ ${ }^{1}$ Interactions Cellulaires Neuroendocrinnienes, UMR/CNRS 6544, Faculte de Medecine Nord, University of Aix-Marseilles II, Boulevard Pierre Dramard, \\ 13015, Marseilles, France, ${ }^{2}$ Department of Neurosurgery and ${ }^{3}$ Laboratory of Biochemistry and Molecular Biology, Assistance-Publique Hopitaux de \\ Marseille, 13385 Marseille, France and ${ }^{4}$ IPSEN, Milford, 01757 Massachusetts, USA \\ (Correspondence should be addressed to A Saveanu; Email: alexandru.saveanu@univmed.fr)
}

\begin{abstract}
Objective: Ten percent of patients with prolactinoma fail to respond with normalization of prolactin (PRL) and tumor shrinkage under dopamine agonist (DA) therapy. The resistance to treatment is linked to a loss of dopamine receptor 2 (D2DR). Prolactinomas express somatostatin (SST) receptor subtypes, SSTR1, 2, and 5. The aim of this study was to determine whether different SST compounds could overcome the resistance to DA in prolactinomas.

Design and methods: The efficacy of SSTR1, SSTR2, and SSTR5 ligands; the universal SST ligand, SOM230; and the chimeric SST-DA compound, BIM-23A760, was compared with cabergoline in suppressing PRL secretion from primary cultures of ten prolactinomas (six DA responders and four DA resistant). Receptor mRNAs were assessed by quantitative PCR.

Results: The mean mRNA levels for D2DR, SSTR1, SSTR2, and SSTR5 were 92.3 $\pm 47.3,2.2 \pm 1.4$, $1.1 \pm 0.7$, and $1.6 \pm 0.6$ copy/copy $\beta$-glucuronidase ( $\beta$-Gus) respectively. The SSTR 1 agonist, BIM-23926, did not suppress PRL in prolactinomas. In a DA-resistant prolactinoma, it did not inhibit $\left[{ }^{3} \mathrm{H}\right]$ thymidine incorporation. The SSTR 5 compound, BIM-23206, produced a dose-dependent inhibition of PRL release similar to that of cabergoline in three DA-sensitive prolactinomas. BIM-23A760 produced a maximal PRL inhibition superimposable to that obtained with cabergoline with a lower $\mathrm{EC}_{50}(0.5 \pm 0.1$ vs $2.5 \pm 1.5 \mathrm{pmol} / \mathrm{l})$. In DA-resistant prolactinomas, BIM-23206 and SOM230 were ineffective. Cabergoline and BIM-23A760 produced a partial inhibition of PRL secretion ( $19 \pm 6$ and $21 \pm 3 \%$ respectively).

Conclusion: Although the SSTRs are expressed in prolactinomas, the somatostatinergic ligands analyzed do not appear to be highly effective in suppressing PRL. D2DR remains the primary target for effective treatment of prolactinomas.
\end{abstract}

European Journal of Endocrinology 158 595-603

\section{Introduction}

Dopamine agonists represent the treatment of choice in prolactin (PRL)-secreting pituitary adenomas (1). They control PRL secretion and cell proliferation by interacting with the dopamine D2 receptor that subsequently activates various transduction pathways (2). D2DR agonists are efficient in the majority of cases, but $10-15 \%$ of patients with prolactinomas fail to obtain PRL normalization and reduction in tumor size even with the most potent dopamine agonist, cabergoline $(3,4)$. These prolactinomas, resistant to dopamine agonists, are usually large and/or invasive, thus surgery cannot be a complete curative treatment. In such tumors poorly or partially responsive to dopamine agonists, an alternative medical treatment should be of real importance. Experimental data have demonstrated that different somatostatin receptor (SSTR) subtypes are expressed at various levels in prolactinomas, SSTR 5 being the most important in the regulation of PRL secretion $(5,6)$. We have previously shown a partial synergistic effect between D2DR and SSTR 5 in suppressing PRL secretion (5). Such an additivity could be useful for hormonal inhibition in prolactinomas resistant to dopamine agonists.

Recently, hybrid molecules with high binding affinity for SSTRs and D2DR have been developed. These molecules, when tested in culture studies from mixed $\mathrm{GH}-\mathrm{PRL}$-secreting tumors partially responsive to SST analog therapy, showed greater efficacy than octreotide or a dopamine D2DR analog in suppressing GH or PRL secretion from mixed somatotroph adenomas in culture studies (7).

In the present study, we analyzed the PRL suppression produced by the ligands directed toward SSTR1, SSTR2, and SSTR5 used alone or in combination 
in prolactinomas sensitive or resistant to dopamine agonists. We also evaluated the efficacy of more complex compounds such as the universal SSTRs ligand, SOM230 (8), and of a dopastatin molecule, BIM-23A760 (9), in suppressing PRL secretion in dopamine-sensitive and -resistant prolactinomas in vitro. The dose-response for suppression of PRL secretion by these compounds was compared with that of cabergoline in order to know whether SST analogs could be of interest in the treatment of prolactinomas resistant to cabergoline.

\section{Design and methods}

\section{Patients}

The present study was approved by the Ethics Committee of the University of Aix-Marseille (AixMarseille, France) and informed consent was obtained from each patient. Ten patients with PRL-secreting pituitary macroadenomas were included in the study (seven men, three women; mean age $42.2 \pm 8.3$ years). The endocrine and neuroradiological characterization of tumors were documented before any treatment. Before surgery, all patients were submitted to medical treatment with the dopamine agonist, cabergoline. Taking into consideration the hormonal response therapy, four patients were considered resistant to medical treatment (P1, P5, P7, and P10), as their mean ( \pm s.e.M.) basal plasma PRL value was $2720 \pm$ $1360 \mu \mathrm{g} / \mathrm{l}$ before treatment and their nadir mean value was $554 \pm 129 \mu \mathrm{g} / \mathrm{l}$ during chronic therapy with $0.5 \mathrm{mg}$ cabergoline daily. The remaining six patients were considered as sensitive to dopamine agonist treatments. Despite normalization of their plasma PRL levels under cabergoline, they were operated on due to intolerance to the drug. Four patients with mixed growth hormone prolactin $(\mathrm{GH}-$ PRL)-secreting pituitary adenoma were also enrolled in the study. All patients underwent transphenoidal surgery. A tissue specimen obtained from the surgical resection of the adenomas was used to quantify mRNA expression of D2DR and SSTR1-5. Another tumoral fragment was used for cell culture studies. Immunohistochemistry confirmed the PRL or GH - PRL character of the selected pituitary tumors. Clinical and immunohistochemical characteristics of prolactinomas and mixed tumors are presented in Table 1.

\section{Quantification of D2DR and SSTR subtypes mRNA expression}

Depending on the tumor, 1-1.5 $\mu \mathrm{g}$ RNA were obtained. One microgram of total RNA was used for cDNA synthesis, as described previously (5). The detection of D2DR and SSTR subtypes mRNA expression was made by performing a real-time quantitative PCR using primer and probes as described previously $(5,10)$. TaqMan Gold nuclease assay was used (Perkin-Elmer, Foster City, CA, USA). The amplification reactions were realized on ABI PRISM 7700 sequence Detection System (Perkin-Elmer), according to the manufacturer's protocol. The D2DR and SSTR subtype mRNA levels were normalized in the same reaction to the $\beta$-Gus mRNA levels for quantification of the results. For each measurement, two independent RT-PCR analyses were performed.

Table 1 Clinical and immunohistochemical characteristics of ten pure prolactinomas (a) and four mixed growth hormone-prolactin (GH-PRL) adenomas (b).

\begin{tabular}{|c|c|c|c|c|c|c|}
\hline Tumor & Age & Sex & & Basal PRL $(\mathrm{ng} / \mathrm{ml})^{\mathrm{a}}$ & Tumor size $(\mathrm{mm})^{\mathrm{b}}$ & IHC \\
\hline \multicolumn{7}{|l|}{ (a) } \\
\hline $\mathrm{P} 1$ & 78 & M & & 4000 & 30 & PRL 90\% \\
\hline P2 & 26 & M & & 6500 & 36 & PRL 90\% \\
\hline P3 & 34 & $\mathrm{~F}$ & & 80 & 35 & PRL $100 \%$ \\
\hline P4 & 37 & M & & 800 & 20 & PRL $100 \%$ \\
\hline P5 & 46 & M & & 5000 & 55 & PRL 40\% \\
\hline P6 & 32 & M & & 4000 & 80 & PRL $100 \%$ \\
\hline P7 & 57 & M & & 880 & 28 & PRL 90\% \\
\hline P8 & 22 & $\mathrm{~F}$ & & 146 & 15 & PRL $100 \%$ \\
\hline P9 & 38 & $\mathrm{~F}$ & & 83 & 18 & PRL $100 \%$ \\
\hline P10 & 52 & M & & 1000 & 35 & PRL $100 \%$ \\
\hline Tumor & Age & Sex & Basal GH $(\mathrm{ng} / \mathrm{ml})^{\mathrm{a}}$ & Basal PRL (ng/ml) ${ }^{a}$ & Tumor size $(\mathrm{mm})^{\mathrm{b}}$ & IHC \\
\hline \multicolumn{7}{|l|}{ (b) } \\
\hline A1 & 26 & $\mathrm{~F}$ & 126 & 58 & 48 & GH $30 \%$, PRL $5-10 \%$ \\
\hline A2 & 31 & $M$ & 59 & 66 & 35 & GH $60 \%$, PRL $15 \%$ \\
\hline \multirow[t]{2}{*}{ A3 } & 53 & M & 10 & 26 & 11 & GH $75 \%$, PRL 5-10\% \\
\hline & 26 & M & 109 & 83 & 48 & GH $30 \%$, PRL 5-10\% \\
\hline A4 & & & & & & \\
\hline
\end{tabular}

IHC, immunohistochemistry; P, prolactinomas; $A$, mixed $\mathrm{GH}+\mathrm{PRL}$ tumor

${ }^{a}$ Serum PRL or GH levels measured before medical therapy.

${ }^{\mathrm{b}}$ Maximal tumor diameter evaluated by MRI. 


\section{Tumor cell culture}

Tissue specimens obtained during transphenoidal surgery were submitted to mechanical and enzymatic dissociation with collagenase at $37^{\circ} \mathrm{C}$ for $30-45 \mathrm{~min}$. The total cell amount was $4 \times 10^{6}$ to $65 \times 10^{6}$ depending on the tumor. Tumor cells were plated at a density of $2 \times 10^{4}$ in 24-well culture dishes coated with extracellular matrix from bovine endothelial corneal cells, as described previously (11). The cells were cultured for 4 days at $37^{\circ} \mathrm{C}$ in a $\mathrm{CO}_{2}$ incubator with Dulbecco's Modified Eagle Medium (DMEM) supplemented with $10 \%$ fetal serum. At the start of the pharmacological studies, the medium was changed to DMEM supplemented with $1 \%$ fetal serum, $1 \%$ transferrin, $1 \%$ selenium and $1 \%$ insulin, and effectors were added at various concentrations $\left(10^{-13}-10^{-7} \mathrm{~mol} / \mathrm{l}\right)$. The cells were incubated with different drugs for $16 \mathrm{~h}$. Each drug concentration was tested in quadruplicate. At the end of the experiments, the medium was removed and stored at $-20{ }^{\circ} \mathrm{C}$ for hormonal assays. All results were expressed as percent (\%) inhibition of PRL release versus control (medium alone).

\section{Pharmacological compounds}

The receptor subtype specificity of each compound is shown in Table 2. The BIM compounds have been provided by Ipsen Inc. (Milford, MA, USA). BIM-23926 is a selective SSTR1 ligand (IC50: $3.6 \mathrm{nmol} / \mathrm{l}$ ). BIM23197 is a preferential SSTR2 agonist with IC50 $0.19 \mathrm{nM} / \mathrm{l}$. BIM-23206 is a SSTR5-selective agonist with IC50 of $2.4 \mathrm{nmol} / \mathrm{l}$. The compound BIM-23A760 is a chimeric molecule capable of interacting with SSTR2, SSTR 5, and D2DR. It shows very high affinity to SSTR2 $\left(\mathrm{EC}_{50}: 0.03 \mathrm{nmol} / \mathrm{l}\right)$ and low affinity to SSTR5 $\left(\mathrm{EC}_{50}\right.$ : $3.7 \mathrm{nmol} / \mathrm{l}$ ) when compared with SST 14 (SRIF14). Its dopaminergic pharmacophore presents with lower affinity than cabergoline for D2DR. SOM230 was supplied by Novartis Pharmaceuticals (Basel, Switzerland). This molecule is a multispecific ligand that, when compared with SRIF14, presents a higher affinity to SSTR5 $\left(\mathrm{EC}_{50}\right.$ : $0.2 \mathrm{nmol} / \mathrm{l})$ but lower affinities to SSTR2 $\left(\mathrm{EC}_{50}: 1 \mathrm{nmol} / \mathrm{l}\right)$ and SSTR1 $\left(\mathrm{EC}_{50}: 9.3 \mathrm{nmol} / \mathrm{l}\right)$. The dopamine agonist cabergoline has been provided by Pfizer (Pharmacia \& Upjohn, Kalamazoo, MI, USA). The SSTR agonists were dissolved as $10^{-3} \mathrm{~mol} / \mathrm{l}$ solutions in $0.01 \mathrm{~mol} / \mathrm{l}$ acetic acid containing $0.1 \%$ purified BSA (Life Technologies Inc). Cabergoline was prepared as $10^{-3} \mathrm{~mol} / \mathrm{l}$ solution in $0.01 \mathrm{~mol} / \mathrm{l}$ acetic acid and $70 \%$ ethanol. All drugs were stored at $-80{ }^{\circ} \mathrm{C}$ as $10^{-3} \mathrm{~mol} / \mathrm{l}$ solutions. For each experiment, a fresh aliquot was used in PBS supplemented with $1 \%$ BSA.

\section{$\left[^{3}\right.$ H]thymidine incorporation proliferation assay}

DNA synthesis was measured in one resistant prolactinoma (P1) that expressed high levels of SSTR1 mRNA using the $\left[{ }^{3} \mathrm{H}\right]$ thymidine incorporation test (12). Cells were cultured at a density of $5 \times 10^{4}$ in DMEM supplemented with $10 \%$ fetal serum. At day 3, the medium was replaced by DMEM with $1 \%$ fetal serum, $1 \%$ transferrin, $1 \%$ selenium and $1 \%$ insulin, and the cells were incubated with the selective SSTR1 ligand, BIM-23926, at different concentrations and cabergoline at $10^{-9} \mathrm{~mol} / \mathrm{l}$. At the end of a $72-\mathrm{h}$ incubation, the medium was collected to perform hormonal measurement. Pharmacological effectors, 12-phorbol-13myristate acetate (PMA; $10^{-7} \mathrm{~mol} / \mathrm{l}$ ) and $5 \mu \mathrm{Ci} / \mathrm{ml}$ $\left[{ }^{3} \mathrm{H}\right]$ thymidine, were subsequently added to cell culture for a further 16-hour incubation. At the end of this period, the cells were washed with PBS and extracted with $10 \%$ trichloroacetic acid (TCA) and $10 \mathrm{M} \mathrm{NaOH}$. Radioactivity incorporation was measured using a scintillation counter.

\section{Hormonal assays}

PRL and GH levels were measured in culture medium using a commercial IRMA kit. The anti-PRL and antiGH monoclonal antibodies were furnished by Immunotech (Beckman Coulter, Marseilles, France). Regarding $\mathrm{PRL}$, the normal values ranged from 1 to $18 \mathrm{ng} / \mathrm{ml}$ in men and 1 to $27 \mathrm{ng} / \mathrm{ml}$ in pre-menopausal women;

Table 2 Human dopamine receptor 2 (D2DR) and somatostatin receptor (SSTR) binding affinities of dopamine agonist (DA) and SST analogs.

\begin{tabular}{|c|c|c|c|c|c|c|}
\hline \multirow[b]{2}{*}{ Compound } & \multirow{2}{*}{$\begin{array}{l}\text { Dopamine } \\
\text { receptor } \\
\text { (IC50: nmol/l) } \\
\text { D2DR }\end{array}$} & \multicolumn{5}{|c|}{ Human somatostatin receptor subtype (IC50: $\mathrm{nmol} / \mathrm{l})$} \\
\hline & & SSTR1 & SSTR2 & SSTR3 & SSTR4 & SSTR5 \\
\hline Somatostatin-14 & & 1.9 & 0.2 & 1.2 & 1.8 & 1.4 \\
\hline BIM-23926 & & 3.6 & $>1000$ & $>1000$ & 833 & 788 \\
\hline BIM-23197 & & 6016 & 0.19 & 26.8 & 3897 & 9.8 \\
\hline BIM-23206 & & 1152 & 166 & 1000 & 1618 & 2.4 \\
\hline BIM-23A760 & 15 & 622 & 0.03 & 160 & 1000 & 3.7 \\
\hline SOM230 & & 9.3 & 1 & 1.5 & $>100$ & 0.2 \\
\hline Cabergoline & 0.3 & & & & & \\
\hline
\end{tabular}

Data for SOM230 are from Bruns et al. (8). The values for the BIM compounds are from Ipsen as previously published (9). 
the coefficient of intra-assay variation was below or equal to 2.8\%; and the coefficient of inter-assay variation was below or equal to $8 \%$. For the $\mathrm{GH}$ assay, the intra- and inter-assay coefficients of variation were below or equal to 1.5 and $14 \%$ respectively.

\section{Statistical analysis}

The results are presented as the mean \pm s.E.M. statistical significance between two unpaired groups was determined by the Mann-Whitney $U$ test. To measure the strength of association between the pairs of variables without specifying dependencies, Spearman rank correlations were used. $P<0.05$ was considered significant for all tests.

\section{Results}

\section{D2DR and SSTR subtypes mRNA expression in prolactinomas and GH-PRL-secreting adenomas}

D2DR, SSTR1, SSTR2, and SSTR 5 mRNAs were found in all prolactinomas, but at very different levels of expression (Table 3). The mean mRNA levels of D2DR, SSTR1, SSTR2, and SSTR5 were respectively 92.3 $47.3,2.2 \pm 1.4,1.1 \pm 0.7$, and $1.6 \pm 0.6 \mathrm{copy} / \mathrm{copy}$ $\beta$-Gus. In all cases, the expression of D2DR was predominant over the SSTR mRNAs. In tumors from DA-sensitive patients, the mean level of D2DR expression was $139 \pm 80$ copy/copy $\beta$-Gus, higher than that measured in tumors from DA-resistant patients $(18 \pm 4$ copy/copy $\beta$-Gus $)(P<0.05)$. SSTR1 was mainly found in tumors from DA-resistant patients. SSTR2 levels were low with the exception of two DA-sensitive tumors (P3 and P4). SSTR 5 expression was variable both in DA-sensitive and -resistant prolactinomas, with two tumors showing high levels of SSTR 5 mRNA in each group (P4, P6, P1, and P7). SSTR3 mRNAs were detected in only three out of ten prolactinomas at very low levels of expression (not shown).

SSTR subtypes expression was also measured in four mixed GH-PRL-secreting adenomas (Table 3). In this small series, the mean mRNA levels of SSTR1, SSTR2, SSTR3, and SSTR 5 were $0.5 \pm 0.2,2.3 \pm 0.8,0.4 \pm 0.1$, and $4.9 \pm 2.2$ copy/copy $\beta$-Gus. SSTR 2 and SSTR 5 mRNA were always coexpressed at a higher mean level than that in prolactinomas, while SSTR 1 was present in three out of four adenomas. In two mixed $\mathrm{GH}-\mathrm{PRL}$ adenomas, the levels of D2DR expression $(8.3 \pm 3.1$ copy/copy $\beta$-Gus) were lower than those measured in prolactinomas.

\section{Effect of SSTR1 agonist, BIM-23926, in prolactinomas}

In order to investigate the putative role of SSTR1 in prolactinomas, we selected three DA-sensitive (P6, P8, and P9) and two DA-resistant (P1 and P7) tumors, expressing SSTR1 mRNA. As shown in Fig. 1A, the selective SSTR1 ligand, BIM-23926, was unable to inhibit PRL release at any concentration even in tumors expressing a high level of SSTR1 mRNA (P1 and P7). The SSTR5 ligand, BIM-23206, produced a dosedependent inhibition of PRL release in two DA-sensitive tumors (P6 and P8). The addition of $10^{-8} \mathrm{~mol} / \mathrm{l}$ of the SSTR1 ligand, BIM-23926, did not significantly modify the dose-response inhibition of PRL secretion

Table 3 Quantitative RT-PCR of dopamine receptor 2 (D2DR), somatostatin receptor (SSTR1), SSTR2, SSTR3, and SSTR5 mRNA expression in ten prolactinomas (a) and four mixed growth hormone and prolactin (GH and PRL) adenomas (b).

\begin{tabular}{|c|c|c|c|c|c|}
\hline \multirow[b]{2}{*}{ Tumor } & \multicolumn{5}{|c|}{ D2DR and SSTR mRNAs (copy/copy $\beta$-Gus) } \\
\hline & D2DR & SSTR1 & SSTR2 & SSTR3 & SSTR5 \\
\hline \multicolumn{6}{|c|}{ (a) } \\
\hline \multicolumn{6}{|c|}{ DA sensitive } \\
\hline P2 & 65 & 0.1 & 0.1 & 0.1 & 0.1 \\
\hline P3 & 144 & 0.1 & 6.5 & 0 & 0.1 \\
\hline P4 & 445 & 0.1 & 1.0 & 0 & 2.1 \\
\hline P6 & 26 & 0.4 & 0.1 & 0 & 4.3 \\
\hline P8 & 13 & 0.2 & 0.5 & 0.1 & 0.5 \\
\hline P9 & ND & 0.9 & 0.1 & 0 & 0.1 \\
\hline \multicolumn{6}{|c|}{ DA resistant } \\
\hline P1 & 15 & 12.4 & 0.1 & 0 & 1.3 \\
\hline P5 & 17 & 0.3 & 0.6 & 0 & 0.1 \\
\hline P7 & 12 & 3.9 & 0.1 & 0.1 & 4.3 \\
\hline P10 & 29 & 13.6 & 0.1 & 0 & 0.1 \\
\hline \multicolumn{6}{|l|}{ (b) } \\
\hline A1 & ND & 0 & 0.4 & 0.3 & 15.2 \\
\hline A2 & ND & 1.4 & 0.8 & 0 & 0.5 \\
\hline $\mathrm{A} 3$ & 4 & 0.4 & 2.2 & 0 & 2.5 \\
\hline A4 & 13 & 0.4 & 6 & 1.1 & 1.5 \\
\hline
\end{tabular}

D2DR and SSTR subtype levels are expressed as copy/copy $\beta$-Gus. $P$, prolactinomas; $A$, mixed GH+PRL tumors. 
$\mathrm{BIM}-23926$

BIM-23206

A

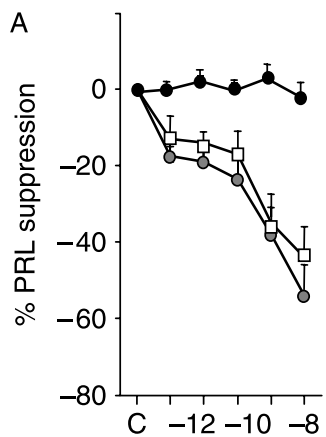

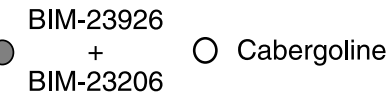

B

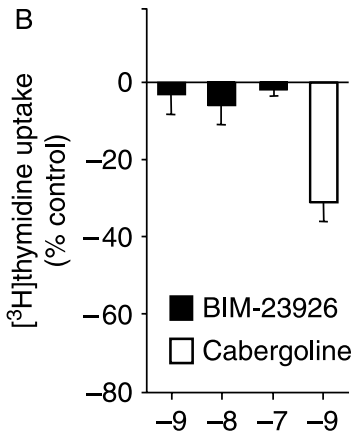

Log (M) drugs

Figure $1(A)$ Mean dose-response PRL suppression in cell culture from prolactinomas using the SSTR1 analog, BIM-23926 (in three DA-sensitive and two DA-resistant prolactinomas), and the SSTR5 analog, BIM-23206, alone or in combination with $10 \mathrm{nmol} / \mathrm{BIM}$ 23926 (in two out of the three DA-sensitive prolactinomas). Results are expressed as the mean +S.E.M. percent PRL suppression versus controls (medium alone). (B) Mean dose-response of $\left[{ }^{3} \mathrm{H}\right]$ thymidine incorporation in cell culture from a DA-resistant prolactinoma (P1) in the presence of the SSTR1 analog, BIM-23926 (black bars) versus cabergoline $1 \mathrm{nmol} / \mathrm{l}$ (white bar). Results are expressed as mean \pm s.E.M. percent of $\left[{ }^{3} \mathrm{H}\right]$ thymidine incorporation compared with control. Each bar represents the mean of four wells.

produced by the SSTR 5 analog $(44 \pm 8 \%$ vs $48 \pm 9$ at 10 nM/l; Fig. 1A).

In order to evaluate the possible role of the SSTR1 compound on proliferation in vitro, we measured DNA synthesis through thymidine incorporation test in tumor $\mathrm{P} 1$. BIM-23926 was tested at $10^{-10}-10^{-7} \mathrm{~mol} / \mathrm{l}$ concentrations and compared with cabergoline at $10^{-9} \mathrm{~mol} / \mathrm{l}$. As shown in Fig. 1B, BIM-23926 was unable to inhibit the $\left[{ }^{3} \mathrm{H}\right]$ thymidine incorporation at any concentration. In the same tumor culture, a $31 \pm 5 \%$ reduction of $\left[{ }^{3} \mathrm{H}\right]$ thymidine incorporation was obtained after incubation with cabergoline at $10^{-9} \mathrm{~mol} / \mathrm{l}$.

\section{SSTR1 agonist versus SSTR2 and SSTR5 agonists in mixed GH - PRL adenomas}

Four mixed GH-PRL-secreting adenomas were incubated with BIM-23926, BIM-23197, and BIM-23206 at a concentration ranging from $10^{-13}$ to $10^{-8} \mathrm{~mol} / \mathrm{l}$. In two tumors (A1 and A3), BIM-23926 did not significantly reduce PRL levels, while a superimposable 42-50\% maximal PRL suppression was obtained with both the SSTR2 and SSTR5 compounds (data not shown). As shown in Fig. 2, in the other two tumors (A2 and A4), maximal PRL inhibition with the SSTR1 agonist was significant $(18 \pm 1 \%$ and $30 \pm 5 \%$ respectively, $P<0.05$ versus control). Nevertheless, in both cases, PRL suppression was obtained at higher concentration than that with the SSTR2 and SSTR 5 analogs. In tumor A2, BIM-23926 produced a maximal PRL

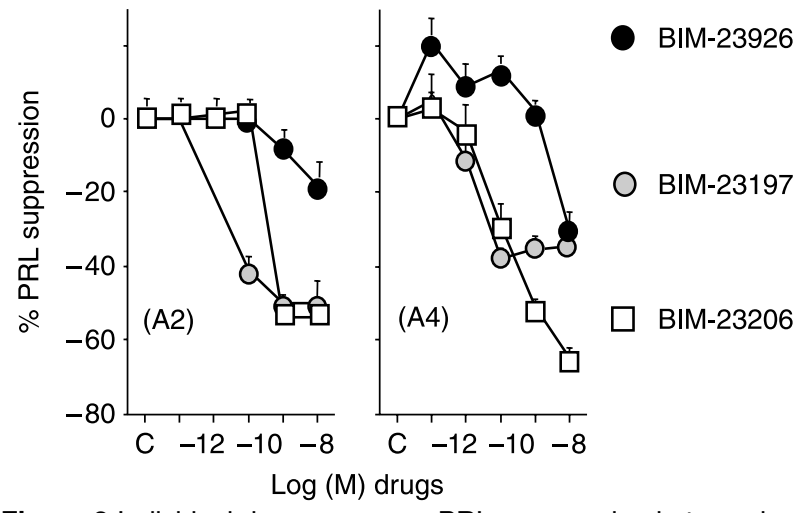

Figure 2 Individual dose-response PRL suppression in two mixed GH-PRL adenomas (A2 and A4) cultured in the presence of BIM23926 (SSTR1 analog), BIM-23197 (SSTR2 analog) and BIM23206 (SSTR5 analog). Results are expressed as the mean \pm S.E.M. percent PRL suppression versus controls (medium alone). Each point represents the mean of four wells.

suppression of $18 \pm 1 \%$ vs $50 \pm 2 \%$ with BIM- 23197 and $54 \pm 1 \%$ with BIM-23206 $(P<0.05)$. In tumor A4, the SSTR 5 analog was more effective in PRL suppression than either the SSTR 2 or SSTR1 analog $(65 \pm 2 \%$ vs $35 \pm 1 \%$ and $30 \pm 5 \%$ respectively, $P<0.05$ ). When GH data were analyzed, the results superimposable to those obtained for PRL were evidenced (data not shown).

\section{Effects of the SSTR2 and SSTR 5 compounds alone or in combination with cabergoline in prolactinomas}

Four DA-sensitive prolactinomas (P2, P3, P4, and P6) and three DA-resistant tumors were analyzed (P1, P7, and P10). The SSTR2 compound, BIM-23197, at nanomolar concentrations, was ineffective on PRL secretion, in two dopamine-sensitive prolactinomas (P2 and P3) even if P3 expressed high SSTR2 mRNA levels. In tumors P4 and P6, a partial lowering of PRL secretion was measured in the presence of BIM-23197 $(40 \pm 2 \%$ vs $70 \pm 3 \%$ for cabergoline, $P<0.05)$ (data not shown). The SSTR5 compound, BIM-23206, produced a dose-dependent inhibition of PRL release in two out of four DA-sensitive prolactinomas. As shown in Fig. 3A, in these two tumors ( $\mathrm{P} 4$ and $\mathrm{P} 6$ ), the maximal PRL suppression by BIM-23206 (68 $\pm 4 \%)$ was similar to that produced by cabergoline $(70 \pm 3 \%)$. The combination of BIM-23206 and cabergoline at equimolar concentrations showed a dose-response inhibition of PRL secretion similar to that of cabergoline alone (maximal PRL suppression: $71 \pm 3 \%$ ).

In the three DA-resistant prolactinomas, cabergoline $\left(10^{-9} \mathrm{~mol} / \mathrm{l}\right)$ produced a $26 \pm 5 \%$ mean maximal inhibition of PRL secretion. In these tumors, the SSTR 5 compound, BIM-23206 (Fig. 3B), or the SSTR2 compound, BIM-23197 (data not shown), partially suppressed PRL secretion at nanomolar concentrations. The coincubation of cabergoline and BIM-23206 


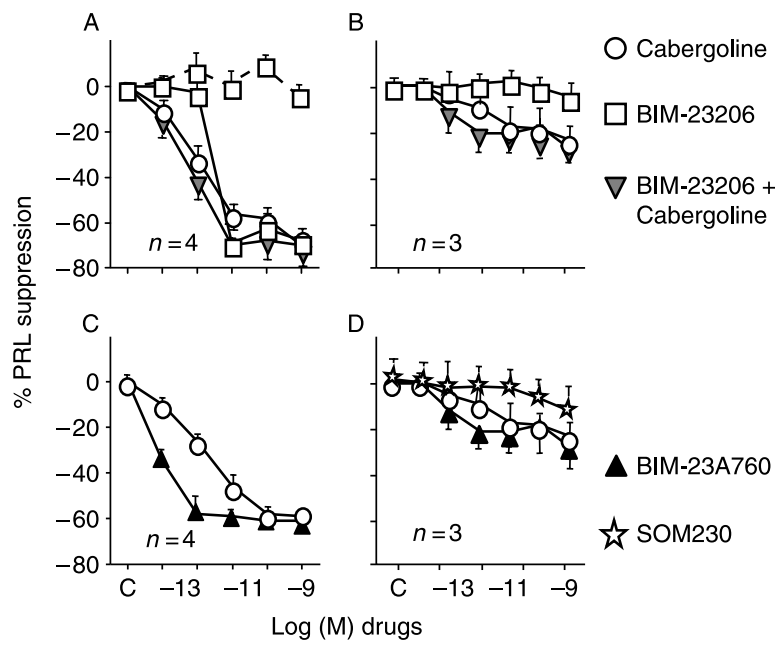

Figure 3 (A) Mean dose-response for PRL suppression in cell culture from four DA-sensitive prolactinomas by the SSTR5 analog, BIM-23206 (open squares, continuous line for 2/4 SSTR5 responders, and dashed line for 2/4 SSTR5 non-responders) and cabergoline (open circles) alone or in combination (grey triangles). (B) Mean dose-response PRL suppression in cell culture from three DA-resistant prolactinomas by the SSTR5 analog, BIM-23206 (open squares) and cabergoline (open circles) alone or in combination (grey triangles). (C) Mean dose-response PRL suppression in cell culture from four DA-sensitive prolactinomas by the dopastatin molecule BIM-23A760 (black triangles) versus cabergoline (open circles). (D) Mean dose-response PRL suppression in cell culture from three DA-resistant prolactinomas by cabergoline (open circles), SOM230 (open stars), and BIM-23A760 (black triangles). Results are expressed as the percent PRL suppression (mean of four wells) versus control value (medium alone).

produced a dose-response inhibition of PRL secretion superimposable to that produced by cabergoline alone (Fig. 3B).

\section{Effects of multiple receptor ligands, BIM- $23 A 760$ and SOM230, in prolactinomas}

In DA-sensitive tumors (Fig. 3C), the maximal PRL inhibition by the chimeric compound BIM-23A760 $(72 \pm 4.3 \%)$ was similar to that obtained by cabergoline. Even if it did not achieve statistical significance, its mean $\mathrm{EC}_{50}(0.5 \pm 0.02 \mathrm{pmol} / \mathrm{l})$ was five times lower than that obtained with cabergoline $(2.5 \pm 1.5 \mathrm{pmol} / \mathrm{l})$. In DA-resistant tumors, BIM-23A760 showed the same trend of higher potency when compared with cabergoline $\left(\mathrm{EC}_{50}\right.$ : $4 \pm 3$ and $28 \pm 24 \mathrm{pmol} / \mathrm{l}$ respectively). Despite such a sevenfold lower $\mathrm{EC}_{50}$, the maximal suppression of PRL secretion with cabergoline and BIM-23A760 were identical (Fig. 3D).

The effectiveness of the SSTR multi-receptor ligand, SOM230 $\left(10^{-13}-10^{-9} \mathrm{~mol} / \mathrm{l}\right)$, on PRL secretion was tested in three resistant tumors (P1, P5, and P10). In these three resistant prolactinomas, in which SSTR1-, SSTR2-, or SSTR 5-selective agonists alone were poorly effective (less than 5\% PRL inhibition), maximal PRL suppression achieved with SOM230 was not significant
( $7 \pm 2.8 \%$ at nanomolar concentration) and again less effective than that of cabergoline (19 $\pm 5.6 \%$; Fig. 3D).

\section{Discussion}

Patients with prolactinomas who fail to obtain PRL levels normalization and tumor size reduction are considered resistant to dopamine agonists treatment (3). Pharmacological resistance to dopamine agonists has become less frequent with the use of cabergoline and represents about $10 \%$ of patients (3). In DA-resistant prolactinomas, a reduction in D2DR receptor levels has been demonstrated and accounts for the partial response to dopamine agonists (13). In our series of ten macroprolactinomas, we confirmed at a quantitative level that mean D2DR mRNA levels in dopamineresistant tumors were significantly lower than those in dopamine-sensitive prolactinomas. However, a great variability in terms of D2DR mRNA levels has been found among sensitive and resistant adenomas and a clear-cut threshold cannot be established between the two categories. Defects in transduction pathways of D2DR in resistant prolactinomas (13) may explain for this overlapping.

In DA-resistant prolactinomas, SST analogs may be of therapeutic interest as different SSTR subtypes were identified in such tumors (14-19). More recently, quantitative mRNA (5) or immunohistochemical studies (20) confirmed the coexpression of three SSTR subtypes (SSTR1, SSTR5, and SSTR2 at a lower level). In the present study, SSTR1 and SSTR 5, associated with SSTR2, were expressed in all prolactinomas, but with important quantitative variations among the tumors. SSTR 1 or SSTR 5 were the predominant SSTR subtypes of mRNA in nine out of the ten analyzed prolactinomas including all DA-resistant macroprolactinomas. SSTR1 and SSTR 5 coexpression was characterized by the differences between high levels of one of such mRNA receptors level and low levels of the others. SSTR 1 was predominant in DA-resistant prolactinomas. Since high SSTR1 expression seems a feature of lactotroph cells (20) and especially in resistant prolactinomas (our data), we investigated the role of this receptor in hormonal regulation and cell proliferation of human prolactinomas using the SSTR1 preferential analog, BIM-23926. The SSTR1 subtype differs from the other SSTRs as it does not internalize but upregulates after prolonged activation in transfected cells (21-23). After ligand binding to the receptor, it does not form homodimers (24). Nevertheless, SSTR1 shares with the other SSTRs the capacity to trigger different signaling transduction pathways $(25,26)$, resulting in an antiproliferative effect (27-29). In human endocrine tumors, SSTR1 modulates hormonal secretion and cell viability in non-secreting pituitary adenomas, human medullary thyroid carcinoma, and mixed GH-PRLsecreting adenomas (30-33). In the present study, 
a suppressive effect of BIM-23926 on hormones release was also evidenced in two out of four mixed GH-PRL adenomas. Nevertheless, in these tumors, the SSTR1 compound proved less potent than the SSTR2 and SSTR 5 compounds. Unexpectedly, BIM-23926, at any concentrations used, could not suppress PRL secretion from pure prolactinomas, whether sensitive or resistant to DA. Similarly, when tested on cell proliferation, BIM23926 did not inhibit DNA synthesis in a pure prolactinoma expressing a high level of SSTR1. Taken together, such different responses of pure lactotrophs versus mixed GH - PRL cells, both expressing the SSTR1 receptor, indicate that the only level of expression of a given receptor cannot predict the responses of the whole cell phenotypes. Presently, the role of SSTR1 in prolactinoma remains unknown.

If SSTR1 by itself has no effect on prolactinoma cells, it may interact with the SSTR 5-mediated suppression of PRL release. Indeed, in transfected cells, SSTR 5-SSTR1 heterodimers formation is preferred to SSTR5 homodimers and results in the modification of ligands binding and the cAMP activation (34). Such a crosstalk between the two SSTR subtypes could not be induced by the ligands in our experiments of coincubation of BIM23926 and BIM-23206 in prolactinoma cells. Similarly, Hofland et al. (35) using the multiple receptor ligand, SOM230, which recognized both SSTR1 and SSTR5, found that only the SSTR 5 mRNA levels were correlated with the SOM230-mediated prolactin suppression in three prolactinomas. In contrast to our previous findings (5), such a correlation was not found in our present limited series. If the SSTR 5 compound, BIM23206, inhibited PRL secretion in the three DA-sensitive tumors (P4, P6, and P8) expressing the highest SSTR 5 mRNA levels, it was ineffective on DA-resistant tumors P1 and P7 also expressing a high amount of SSTR 5 mRNA. Such a combined absence of responsiveness to the SST and dopamine agonists suggests postreceptors defect(s) in the transduction pathways (13). In our limited experience, the three DA-resistant tumors non-responsive to the SSTR 5 analog, BIM-23206, were equally non-responsive to SOM230.

We have previously shown that a SSTR 5 analog, BIM23268, combined with a D2DR analog, quinagolide, produced a partial additive effect on PRL suppression of prolactinomas (5). The chimeric compound, BIM23A760, binds SSTR2, SSTR5, and also D2DR. In culture studies of mixed $\mathrm{GH}-\mathrm{PRL}$ adenomas, BIM23A760 suppressed PRL levels with a better efficacy than either octreotide or SSTR2-D2DR drug (9), with putative contribution of SSTR2, SSTR5, and D2DR affinities. Moreover, in acromegaly, this dopamine-SST ligand was more potent and more long lasting to inhibit GH secretion than its single components used alone or in combination (9). Such a synergistic effect was not found in prolactinomas in the present study. BIM-23A760 showed a better but non-statistically significant $\mathrm{EC}_{50}$ in suppressing PRL secretion when compared with cabergoline in both DA-sensitive and -resistant prolactinomas, without maximal PRL suppression improvement. These findings in prolactinomas are far away from the synergistic cooperation of these two receptors in cAMP suppression demonstrated in experimentally transfected cells (36). Recently, BIM23A760 was found to suppress PRL in a similar manner to D2DR agonists in primary rat pituitary cell cultures and MMQ prolactin-secreting rat cell line (37). These results seem roughly similar to our prolactinoma data and confirm the crucial role of D2DR affinity for the PRL suppression by BIM-23A760.

In conclusion, we demonstrated that SSTR1 analogs have no effect on PRL suppression and cell proliferation in prolactinomas. The SSTR1 analog does not modify SSTR5-mediated PRL suppression. The SSTR5 preferential analogs suppress PRL secretion in a majority of dopamine-sensitive prolactinomas never exceeding cabergoline maximal suppressive effects, but proved ineffective on DA-resistant tumors. In this limited series, the universal SSTR ligand, SOM230 was also ineffective on PRL suppression in these tumors. Finally, the chimeric dopastatin compound, BIM-23A760, suppressed PRL at a slightly lower concentration when compared with cabergoline. Whether or not such a partial acute improvement will be of therapeutical interest remains to be demonstrated by long term, in vivo, studies.

\section{Acknowledgements}

This work has been partially supported by a grant from Ipsen and the Association for Development of Medical Research (ADEREM), Marseilles.

\section{References}

1 Casanueva FF, Molitch ME, Schlechte JA, Abs R, Bonert V, Bronstein MD, Brue T, Cappabianca P, Colao A, Fahlbusch R, Fideleff H, Hadani M, Kelly P, Kleinberg D, Laws E, Marek J, Scanlon M, Sobrinho LG, Wass JA \& Giustina A. Guidelines of the Pituitary Society for the diagnosis and management of prolactinomas. Clinical Endocrinology 200665 265-273.

2 Missale C, Nash SR, Robinson SW, Jaber M \& Caron MG. Dopamine receptors: from structure to function. Physiological Reviews 1998 78 189-225.

3 Molitch ME. Pharmacologic resistance in prolactinoma patients. Pituitary 20058 43-52.

4 Gillam MP, Molitch ME, Lombardi G \& Colao A. Advances in the treatment of prolactinomas. Endocrine Reviews 200627 485-534.

5 Jaquet P, Ouafik L, Saveanu A, Gunz G, Fina F, Dufour H, Culler MD, Moreau JP \& Enjalbert A. Quantitative and functional expression of somatostatin receptor subtypes in human prolactinomas. Journal of Clinical Endocrinology and Metabolism $1999 \mathbf{8 4}$ 3268-3276.

6 Shimon I, Yan X, Taylor JE, Weiss MH, Culler MD \& Melmed S. Somatostatin receptor (SSTR) subtype-selective analogues differentially suppress in vitro growth hormone and prolactin in human 
pituitary adenomas. Novel potential therapy for functional pituitary tumors. Journal of Clinical Investigation $1997 \mathbf{1 0 0}$ 2386-2392.

7 Jaquet P, Gunz G, Saveanu A, Dufour H, Taylor J, Dong J, Kim S, Moreau JP, Enjalbert A \& Culler MD. Efficacy of chimeric molecules directed towards multiple somatostatin and dopamine receptors on inhibition of $\mathrm{GH}$ and prolactin secretion from $\mathrm{GH}$-secreting pituitary adenomas classified as partially responsive to somatostatin analog therapy. European Journal of Endocrinology 2005153 135-141.

8 Bruns C, Lewis I, Briner U, Meno-Tetang G \& Weckbecker G. SOM230: a novel somatostatin peptidomimetic with broad somatotropin release inhibiting factor (SRIF) receptor binding and a unique antisecretory profile. European Journal of Endocrinology $2002146707-716$.

9 Jaquet P, Gunz G, Saveanu A, Barlier A, Dufour H, Taylor J, Dong J, Kim S, Moreau JP \& Culler MD. BIM-23A760, a chimeric molecule directed towards somatostatin and dopamine receptors, vs universal somatostatin receptors ligands in GH-secreting pituitary adenomas partial responders to octreotide. Journal of Endocrinological Investigation 200528 21-27.

10 Saveanu A, Lavaque E, Gunz G, Barlier A, Kim S, Taylor JE, Culler MD, Enjalbert A \& Jaquet P. Demonstration of enhanced potency of a chimeric somatostatin-dopamine molecule, BIM-23A387, in suppressing growth hormone and prolactin secretion from human pituitary somatotroph adenoma cells. Journal of Clinical Endocrinology and Metabolism 200287 5545-5552.

11 Jaquet P, Gunz G \& Grisoli F. Hormonal regulation of prolactin release by human prolactinoma cells cultured in serum-free conditions. Hormone Research 198522 153-163.

12 Florio T, Thellung S, Arena S, Corsaro A, Spaziante R, Gussoni G, Acuto G, Giusti M, Giordano G \& Schettini G. Somatostatin and its analog lanreotide inhibit the proliferation of dispersed human non-functioning pituitary adenoma cells in vitro. European Journal of Endocrinology 1999141 396-408.

13 Pellegrini I, Rasolonjanahary R, Gunz G, Bertrand P, Delivet S, Jedynak CP, Kordon C, Peillon F, Jaquet P \& Enjalbert A. Resistance to bromocriptine in prolactinomas. Journal of Clinical Endocrinology and Metabolism 198969 500-509.

14 Nielsen S, Mellemkjaer S, Rasmussen LM, Ledet T, Astrup J, Weeke J \& Jorgensen JO. Gene transcription of receptors for growth hormone-releasing peptide and somatostatin in human pituitary adenomas. Journal of Clinical Endocrinology and Metabolism 1998 83 2997-3000.

15 Miller GM, Alexander JM, Bikkal HA, Katznelson L, Zervas NT \& Klibanski A. Somatostatin receptor subtype gene expression in pituitary adenomas. Journal of Clinical Endocrinology and Metabolism 199580 1386-1392.

16 Murabe H, Shimatsu A, Ihara C, Mizuta H, Nakamura Y, Nagata I, Kikuchi H \& Nakao K. Expression of somatostatin receptor (SSTR) subtypes in pituitary adenomas: quantitative analysis of SSTR2 mRNA by reverse transcription-polymerase chain reaction. Journal of Neuroendocrinology 1996 8 605-610.

17 Hofland LJ, De Herder WW, Visser-Wisselaar HA, Van Uffelen C, Waaijers M, Zuyderwijk J, Uitterlinden P, Kros MJ, Van Koetsveld PM \& Lamberts SW. Dissociation between the effects of somatostatin (SS) and octapeptide SS-analogs on hormone release in a small subgroup of pituitary- and islet cell tumors. Journal of Clinical Endocrinology and Metabolism 199782 3011-3018.

18 Panetta R \& Patel YC. Expression of mRNA for all five human somatostatin receptors (hSSTR1-5) in pituitary tumors. Life Sciences 199556 333-342.

19 Greenman Y \& Melmed S. Expression of three somatostatin receptor subtypes in pituitary adenomas: evidence for preferential SSTR 5 expression in the mammosomatotroph lineage. Journal of Clinical Endocrinology and Metabolism 199479 724-729.

20 Thodou E, Kontogeorgos G, Theodossiou D \& Pateraki M. Mapping of somatostatin receptor types in GH or/and PRL producing pituitary adenomas. Journal of Clinical Pathology 200659 274-279.
21 Patel RC, Kumar U, Lamb DC, Eid JS, Rocheville M, Grant M, Rani A, Hazlett T, Patel SC, Gratton E \& Patel YC. Ligand binding to somatostatin receptors induces receptor-specific oligomer formation in live cells. PNAS 200299 3294-3299.

22 Hukovic N, Rocheville M, Kumar U, Sasi R, Khare S \& Patel YC. Agonist-dependent up-regulation of human somatostatin receptor type 1 requires molecular signals in the cytoplasmic C-tail. Journal of Biological Chemistry 1999274 24550-24558.

23 Nouel D, Gaudriault G, Houle M, Reisine T, Vincent JP, Mazella J \& Beaudet A. Differential internalization of somatostatin in COS-7 cells transfected with SST1 and SST2 receptor subtypes: a confocal microscopic study using novel fluorescent somatostatin derivatives. Endocrinology $1997 \mathbf{1 3 8} 296-306$.

24 Rocheville M, Lange DC, Kumar U, Sasi R, Patel RC \& Patel YC. Subtypes of the somatostatin receptor assemble as functional homo- and heterodimers. Journal of Biological Chemistry 2000275 $7862-7869$.

25 Chen L, Fitzpatrick VD, Vandlen RL \& Tashjian AH, Jr. Both overlapping and distinct signaling pathways for somatostatin receptor subtypes SSTR1 and SSTR2 in pituitary cells. Journal of Biological Chemistry 1997272 18666-18672.

26 Buscail L, Delesque N, Esteve JP, Saint-Laurent N, Prats H, Clerc P, Robberecht P, Bell GI, Liebow C, Schally AV, Vaysse N \& Susini C. Stimulation of tyrosine phosphatase and inhibition of cell proliferation by somatostatin analogues: mediation by human somatostatin receptor subtypes SSTR1 and SSTR2. PNAS 1994 $912315-2319$.

27 Arena S, Pattarozzi A, Massa A, Esteve JP, Iuliano R, Fusco A, Susini C \& Florio T. An intracellular multi-effector complex mediates somatostatin receptor 1 activation of phospho-tyrosine phosphatase eta. Molecular Endocrinology 200721 229-246.

28 Florio T, Thellung S, Arena S, Corsaro A, Bajetto A, Schettini G \& Stork PJ. Somatostatin receptor 1 (SSTR1)-mediated inhibition of cell proliferation correlates with the activation of the MAP kinase cascade: role of the phosphotyrosine phosphatase SHP-2. Journal of Physiology 200094 239-250.

29 Cattaneo MG, Taylor JE, Culler MD, Nisoli E \& Vicentini LM. Selective stimulation of somatostatin receptor subtypes: differential effects on Ras/MAP kinase pathway and cell proliferation in human neuroblastoma cells. FEBS Letters 2000 481 271-276.

30 Zatelli MC, Piccin D, Tagliati F, Ambrosio MR, Margutti A, Padovani R, Scanarini M, Culler MD \& Degli Uberti EC. Somatostatin receptor subtype 1 selective activation in human growth hormone (GH)- and prolactin (PRL)-secreting pituitary adenomas: effects on cell viability, GH, and PRL secretion. Journal of Clinical Endocrinology and Metabolism 200388 2797-2802.

31 Zatelli MC, Piccin D, Bottoni A, Ambrosio MR, Margutti A, Padovani R, Scanarini M, Taylor JE, Culler MD, Cavazzini L \& Degli Uberti EC. Evidence for differential effects of selective somatostatin receptor subtype agonists on alpha-subunit and chromogranin a secretion and on cell viability in human nonfunctioning pituitary adenomas in vitro. Journal of Clinical Endocrinology and Metabolism 200489 5181-5188.

32 Zatelli MC, Piccin D, Tagliati F, Bottoni A, Luchin A, Vignali C, Margutti A, Bondanelli M, Pansini GC, Pelizzo MR, Culler MD \& Degli Uberti EC. Selective activation of somatostatin receptor subtypes differentially modulates secretion and viability in human medullary thyroid carcinoma primary cultures: potential clinical perspectives. Journal of Clinical Endocrinology and Metabolism 2006 $912218-2224$.

33 Matrone C, Pivonello R, Colao A, Cappabianca P, Cavallo LM, Del Basso De Caro ML, Taylor JE, Culler MD, Lombardi G, Di Renzo GF \& Annunziato L. Expression and function of somatostatin receptor subtype 1 in human growth hormone secreting pituitary tumors deriving from patients partially responsive or resistant to longterm treatment with somatostatin analogs. Neuroendocrinology 200479 142-148.

34 Grant M, Patel RC \& Kumar U. The role of subtype-specific ligand binding and the C-tail domain in dimer formation of human somatostatin receptors. Journal of Biological Chemistry 2004279 $38636-38643$. 
35 Hofland LJ, Van Der Hoek J, Van Koetsveld PM, De Herder WW, Waaijers M, Sprij-Mooij D, Bruns C, Weckbecker G, Feelders R, Van Der Lely AJ, Beckers A \& Lamberts SW. The novel somatostatin analog SOM230 is a potent inhibitor of hormone release by growth hormoneand prolactin-secreting pituitary adenomas in vitro. Journal of Clinical Endocrinology and Metabolism 200489 1577-1585.

36 Rocheville M, Lange DC, Kumar U, Patel SC, Patel RC \& Patel YC. Receptors for dopamine and somatostatin: formation of heterooligomers with enhanced functional activity. Science $2000 \mathbf{2 8 8}$ 154-157.
37 Gruszka A, Ren SG, Dong J, Culler MD \& Melmed S. Regulation of growth hormone and prolactin gene expression and secretion by chimeric somatostatin-dopamine molecules. Endocrinology 2007 148 6107-6114.

Received 16 January 2008

Accepted 30 January 2008 